SBD, INWS , SHI III-6

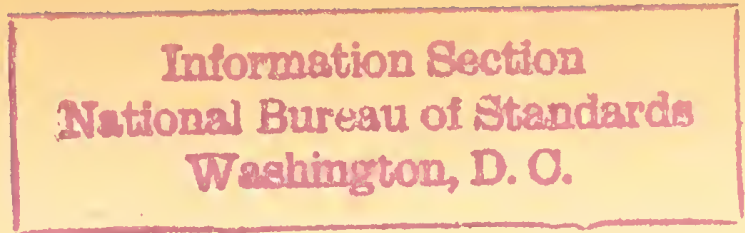

U. S. DEPARTNENT OF COMIERCE NATIONAI BUREAU OF STANDARDS Washington
Letter

Circular

IC 818

(Supersedes IC 467 )

February 21, 1946

FLAIEPROOFING OF TENTILES

CONTHNTS

Page

I. Principles of flameproofing .............. 2

1. Function of flameproofine chemicals ....... 2

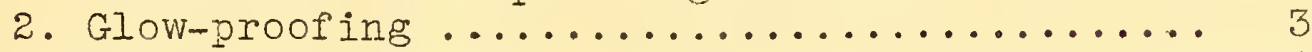

II. Historical notes ..................... 4

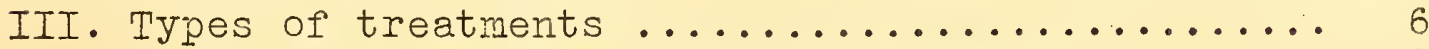

1. Fire and weather resistant finishes ....... 6

2. Flameproofing treatments suitable for

clothing and indoor purposes .......... 7

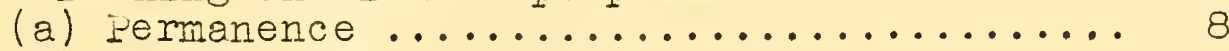

(b) Method of application ............ 8

(c) Required loadings ................. 9

(d) Application in commercial laundry

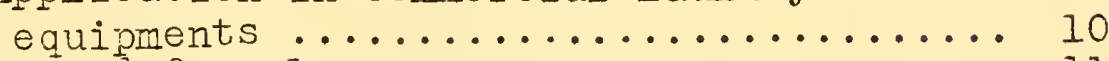

IV. Processes and formulas ................... II

1. Processes combining fireproofing and

weatherproofing, type $1 \ldots \ldots \ldots \ldots \ldots \ldots \ldots \ldots$

2. Water-resistant finishes, type $2 \ldots \ldots \ldots \ldots 13$

3. Water-soluble treatiments, type $3 \ldots \ldots \ldots \ldots 15$

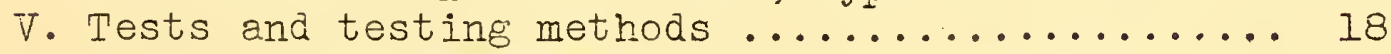

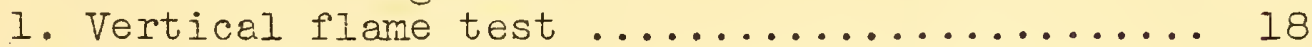

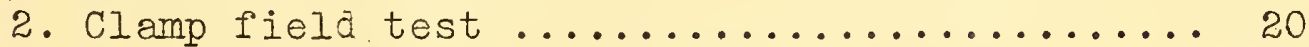

3. Horizontal rate-of-burning test .......... 21

4. Conditioning of test samples ........... 22

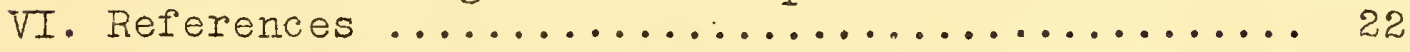

The widespread public interest in the flameproofing of textiles, as evidenced by the numerous requests for information on the subject, prompted the preparation of this circular. It includes condensed sections on (I) the principles, (II) the history of flameproofing, (III) types of treatments, (IV) formulas for various processes, (V) tests anā testing methods, and (VI) a brief list of publications on the subject. 


\section{PRINCIPLES OF FIAIIEPROOFING}

Textile flameproofing is concerned chiefly with cotton, rayon, and other fibers of vegetable origin. Such fibers are composed of cellulose which, when heated, decomposes into readily combustible gaseous and tarry products. Wool and other fibers of animal origin are less flammeble, largely because the protein constituents decompose on heating to liberate nonflammable nitrogenous gases. The recently developed, truly synthetic fibers, nylon and Vinyon, are elso less filamable tinan cotton or rayon and do not present a serious fire hazera, although they melt at relatively low temperatures.

Glass fibers are incombustible, and the amount of oil and coatings used in the finished cloth is generally not large enough to introduce a fire hazard.

Complete fireproofing of combustible textiles -- making them fully resistant to burning, charring, and decomposition at high surrounding temperatures -- has not yet been achieved, and is probably not possible. The most that can be expected of a flameproofed fabric is that it will resist ignition by a match or similar small source of heat, or that, if once ignited, it will not continue burning upon removal of the source of ignition. Such flameproofing may be accomplished by impregnating or coating the cloth with preparations of various chemicals, either singly or mixed.

\section{Function of Flameproofing Chenicals}

There are several types of action by which the compounds are believed to fleneproof the fabric. They mey be listed as follows:

(a) Modification of the cellulose molecule chemically by the flameproofing agent either before or at the time of combustion, one effect of which is alteration in the decomposition products fomed, i.e. less of the very flammable tarry products, and more of the nonvolatile charred resiaue.

(b) The production of a flux or fom from the fireproofing agent by the heat of the fire, thus coating the fibers of the fabric and retarding combustion.

(c) The evolution of noncombustible gases or vapors on decomposition of the flameproofing agent which dilute the combustible gases from the cellulose decomposition or tend to blanket the fabric and exert a smothering influence on the $\mathrm{el}$ ame. 
(d) The physical weighting of the fabric with non"combustible material, thus rendering it less susceptible to ignition and less able to perpetuate its own kinding temperature.

Many of the flaneproofing compounds may combine two or more types of action, and most investigators at present believe that a chemical modification of the cellulose probably represents the major result of the more effective treatments. In view of the small amount of a good flameproofing agent required for effective protection, it is scarcely plausible that either (c) or (d) can account entirely for the results obtained. The formation of a glaze (b) could more readily be accepted as a complete explanation of the action of such compounds as borax and boric acia, but there is indication that they also modify the cellulose in their action. Thus, Ramsbottom and snoad (1) I/ in on extensive study using borax, boric acid, and mixtures of the two, conclude that they modify the action of heat on the fabric, lowering the temperature at which blackening of the fabric occurs and causing a reduction in the amount and the degree of flammability of the volatile combustibles procuced. Their study indicated, in general, that efficient flaneproofers increase the destructive action of heat on cellulose, lowering the blackening temperature of the fabric. Many of the ammonium salts of inorganic acids are efficient fire retardants and upon being heated evolve ammonia gas which may aid in reduction of flame propagation, but the acid and its reaction on the fabric may play the dominant part. Work recently carried out for the Quartermaster Corps of the United States Army also indicates that even small arounts of fire retardants modify the action of heat on cellulose, increasing the production of char, water, and nonflammable gas, and substantially reducing that of volatile tarry matter.

\section{Glow-Proofing}

The satisfactory flemeproofing of a fabric does not always prevent the occurrence of afterglow, that is, the continued slow burning of the fabric by glow even though it does not flame after ignition. If this afterglow is confined to the already charred areas it is not usually serious, but when it spreads extensively into the unamaged fabric it is a continued hazard and may completely consume the fabric. Good glow-proofers appear to function either by coating the fibers, thus cutting off a sufficient air supply, or by chemically altering the course of the oxidation reaction. Among the effective glowproofers may be mentioned ammonium phosphate, and the urea phosphates which, on heating, yield phosphorus pentoxide and in the presence of free carbon 
appear to react chemically to control afterglow. Boric aoid and such compounds as zinc borate, which yield boric oxide on heating, also function as effective gloworoofers, and recently some organic compounas have been found efficient.

\section{EISTORICAI NOTES}

The subject of fireproofing has been one of great interest since ancient times. It is said that the Romens attempted to fireproof their houses and war vessels by dipping the wood in a bath of vinegar and clay. An early mention of textile flameproofing occurs in a peper published in 1638 by Nikolas Sabbattini, who urged reforms in the construction and furnishing of Italian theaters from the standpoint of fire prevention, and recommended that the color used in painting theaters and scenery should be mixed with clay or gypsum.

In 1735 Jonathan Wild, of Englend, was granted a patent dealing with o flameproofing mixture composed of alum, ferrous sulfate, and borax. Wild's work wes fo-lowed by other investigations and the subseruent history of textile flameproofing contains the names of many experimenters, of whom only a fow can receive montion here.

Gay-Lussac (2) in 1821 published the results of an investigation suggested by Louj.s XVIII, in which he determined the fire-retardant properties imparted by numerous salts when deposited on linen and hemp cloth in the amounts of 10 and 20 percent. He found that aminim phosphats, equal parts of ammonium chloride and ammonium phosphate, and equal parts of amonium chloride and borax, were effective.

A worthy contribution was inade by Versmenn and oppenheim (3) who in 1859 reported to the Bitish Association for the Advancement of science the results cf a study of the protective action on muslin of 40 chemicals. Their work was conducted on a commercial scale as well as in the labor tory. They found that only five of the salts and mixtures tied had practical value: ammonium phosphate; sodium-ampirir phosphate; ammonium phosphate and ammonium chloride mixture; unonium sulfate; and sodium tungstate.

At the instigation of Freeman (4), Miprle and Fay did considerable work oil flameproofing theate: scenery. Ammonium phosphate was found to be the most effectrra of meny salts tried but was conducive to the growth of mild end mildew. Reporting the results, Freeman staies criphticelly that although many substances were found that wou' o mal'xe gauze and canvas proof against ignition by small flams, "rowing was found that would prevent the instent blining with a rusn of flame when the test was made with a strorig blaze on closely hung sheets of canvas." In later work on scenery, King and Florentin (5) of 
the Paris Municipal Laboratory found a solution of borax and boric acid in a $6: 5$ ratio to be the most suitable of many agents tried.

Ramsbottom and Snoad (1), working at the Royal Aircraft Establishment with cotton fabric, corroborated the effectiveness of a borax-boric acid mixture, but preferred a $7: 3$ ratio to the proportions of rling and Florentin.

Perkin (6), seeking a permanent process for cotton flannelettes and other highly flemeble cotton goods, found the best treatment to be stannic oxide precipitated on the fibers by a method given in section IV.

The development of a commercial method of producing sulfamic acid (7) led to the use of armonium sulfamate as a new and effective flameproofer (8), which hes been made the basis of a proprietary product on the merket.

Other investigators have aimed to combine the desirable properties. of borates and phosphates without use of ammonium salts, which sometimes produce a progressive and destructive acidity by gradual loss of ammonia. A şisfactory flameproofer in the form of a complex boro-pnospnate resin (9) has been developed and made the basis of enotiner proprietary product.

In the recent emergency the armed services became deeply interested in the problem of flameproofing textiles and considercble work has been carried out on the fundamental principles of flemeproofing as well as its practicel applicetions. The Chemical Warfare Service Development Laboratory at Massachusetts Institute of Technology (10) has developed a water-resistant formule using entimony oride in a vinylite binder which is described in Section IV. The IVational Research Council Ieboretories at Columbie. University heve cerried out extensive investigations in the field. The water-soluble formula which they have recently recommended to the Army Quartermaster corps for generel clothing use also appears in section IV. They consicer this formula as satisfectory as any of the water-soluble group with resject to both flameproofing and gilowproofing.

The work of Dr. Viartin Leatherman (11) is representative of the basic development of the present itire and weather resistant finishes for cotton duck. Dr. Leatherman's early work was concerned with improvements in the perkin process, particularly in preventing afterglow by applying an overcoat of chlorinated resin or rubber to the treated fabric. These materials were known to have slow-burning properties. He found that the flameproofing oxides (tho stannic oxide of the perkin process and numerous others) can be mixed with the chlorinated 
resin or oil with retention of the flame and weather resistant properties, thus eliminating the more complicated two-bath method of impregnation.

Interest in the flameproofing field is still very active and a number of laboratorịes are working on now or improved formulas. Commercial flameproofing of fabrics at the time of manufacture is feasible only when the treatment has a reasonable degree of permenence to laundering or water leaching. The present fire and we ether resistant finishes for canvas and duck meet this requirement fairly well and factory treatment is comon. However, flameproofing will not be of general interest to comercial finishers of fine fabrics until permanent treatments are developed which are effective in weightings compatible with the use.s of such fabrics. Some promise along this line is found in the fiold of oil-in-water and water-inoil emulsions, and in treatments which vill decidedly modify the cellulose molecule. Interest is elso centered in the possibility of treating fibers before spinning to produce a permanently flanoproofed materiel which will require no further treatment after fabrication.

\section{TYPES OF TREATIENTS}

Three general types of fire-reterdant treatments are in use at present. One combines wectherproofing with fireproofing and is commonly applied to cenvas and auck intended for tentage, awnings, and siniler outdoor purposes. The other two are either partially or completely removed by laundering or water leaching end are aplicable for clothing, decorations, and generel indoor purposes.

\section{Fire end Weather Resistant Finishes (Type 1, section IV)}

The requirements of the armed forces have given considerable impetus to the recent development of improved finishes for heavy feorics intended for oui.joor exposure, combining flame and weather asistance. For the nost pert, the present finishes of this type are designed to meet requirements similar to those of Federal Specificetion CCC-D-746 for Fire, Water, and Wather Resistant Cotton Duck ( 12$)$.

Since these finishes are designed to withstand outdoor exposure, flame tests after weathering, as well, as on the freshIy treated fabric, are essenticl in juaging the effectiveness of a treatment. Accelereted weathering tests havo been developed which atumpt to produce in a short time the effects of longer natural exposures. In the devolopinent of specification requirements, the National Eureau of Standards carried oui an investigation of the correlation between the effects of natural exposure and those of an accelerated weathering machine, in which the material is exposed to the radiation from a carbon arc and to 
periodic applications of water spray. Tests were also made of the effects of water spray alone upon well-treated awning material, with results inaicating that reinfell alone is not of primary importance in weathering es it effects flammability, but that the greatest deterioration is probably due to sunlight, and the shock of interspersed sunlight and rainfall. Thus, artificial rainfall apolied intermittertly over a 40-hour period, equiveient in amount to about 12 years of natural rainfall in washington, D. C., produced little loss in flameproof properties. On the other hand, naturel weathering in washington, D. C., for six months and one year, and artificial weathering (carbon arc and weter sprey exposure) for 15 and 30 days had a much greater effect. The accelerated weathering can only approximate a speed-up of the natural weathering process. It is apparent that the greet verietions in clinate mean a corresponding variation in the actual weathering a fabric may be required to withstand.

\section{Flameprooping Treatments Suiteble for Clothing and Indoor Furposes}

Several processes that deposit a water-insoluble compound in the fabric have been developed which vill withstand a number of launderings, but none of them is entirely satisfactory for general use (Type 2 , Section IV). Their aplication is often difficult and complicated and is best cerried out in a commercial finishing plant. The antimony oxide-Vinylite process (No. 2 in section IV); one of the nost recent of such developments, gives promise of being suitable for work clothing and perhaps such materiels as uplolstery and carpeting, but it so stiffens the fabric that a fairly severe softening process is necessary, and its value for very fine meteriels is doubtful.

\section{A number of the flameproofers suiteble for the finer} fabrics, such as emonium salts, borates, phosphates, silicates, ete. (Type 3, Section IV), have been known and used for curtains and interior decorations for meny years. A few, such as ammonium and urea sulfemates, borophosinete resins, and alkyl end aryl phosphates cnd borates, are of rore recent introduction. In the choice of a flameproofing agent, several fectors, the importance of which is dependent upon the intended use of the fabric, must be considered. Some chomiccls discolor the cloth or injure it when it is ironed; others waken it or make it unduly harsh or heavy. Chomicals which absorb noisture from the air may promote growth of mildew ana cacumulction of dirt. Those which give of r moisture to the air and cause dusting or discoloration, are also undesirebie. Crystalline compounds deposited from concentrated solutions mey ner the appearance of the fabric. Some chomicals cost too much or are toxic. Nevertheless, in general, it is not difficult to select a formula suitable for the desired purpose. 


\section{(a) Permanence}

The problem of permanence has not been completely solved for any of the treatments suitable for fine fabrics. All of the usual water soluble chemicals are removed by laundering or water leaching and the treatment must be renewed after each laundering. Nost chemicals will be worn away or dusted out of the fabric with continued use or handing. In-some recent wear tests made with workmen's clothing that had been flameproofed with a boray-boric acid treatment, the flameproofing treatment remained entirely effective after two weeks of severe wear. After one month's use some parts of the garments showed a considerable loss in flaneproofing but reasonable efficiency was retained in most areas.

Some chemicals, boric acid in perticular, are slightly volatile and are slowly dissipeted over a long period of time. As a result of indoor sunlight aging tests made at the Bureau of standeras, it was concluded that good water-soluble treatments will give protection of indoor decorations for periods from 6 montins to 2 years if the materials are not laundered. The period of retention depends both upon the flameproofing treatment used and the fabric treated. A lightweight white muslin deteriorated more rapidly than a heavier black velveteen.

Therefore, most of the treatments cennot be depended upon to give protection indefinitely without renewal.

Better success has been realized in the development of treatments resistive to dry cleaning solvents since the chemicals in general use are less soluble in such solvents than in water. It should be remembered, however, that present commercial ary cleaning procedures employ water-dissolved soaps which may remove a considerable part of flameproofing agents not affected by dry cleaning solvents alone. A number of proprietary products justifiably clained to be resistent to pure dry cleaning solvents woula not resist the regular dry cleaning process on this account.

\section{(b) Iiethod of Application}

Soluble flameproofing agents are generelly applied from water solution by immersion, brushing, or spraying, followed by drying. The method of epplication may have considerable effect on the success of the treatment. Hot solutions will generally give better penetration, but in some cases their use is undesirable. Borax and boric acid, for instance, can be most readily dissolved in hot water, but it is advisable to cool the solution to aproximately room temperature befure apnlication, as the hot solution appears to have a greater tendering effect upon the fabric. Dip ing the materiel insures nore complete penetration than brushing or spraying. With the latter methods 
a number of successive aplications, with drying between then, may be reruired before effective protection is achieved. For best results e.l sizing or dressing should be. washed out of the fabric before treatment. Where thjs is not feasible, the addition of $\varepsilon$ sriell amount (about 0.1 to 0.2 percent by weight) of an effective wetting agent to the treating solution will aid wetting and penetration into closely woven or heavily sized material.s.

A more uniforn distribution of the salts will be maintained if the articles can be dried in horizontal position. Drying in verticel position permits a cortain amount of dreinage of the solution, particularly from upper areas, depending on the wetness of the wrung articles. If horizontel drying is not feasible, it will be advisablo to slighely increase the weighting applied in order to allow for sone dreinage. Ineterials treated with wator-soluble comoounds should not be sprinkled and rolled bofore ironing since an unsightly spotting from the chemicals may result. Dampening should be done with a steam. cloth or siniler arrangement at the time of ironing. Cero should be exercised to avoid discoloration from a very hot iron.

\section{(c) Required Loadings}

The weighting with flaneproofing treatnents necessary for adecuate protection will very with the fcbric treated, lighter weight fabrics requiring somewhat heavicr loadings. In general, the water-soluble chemic is should be c.plied in weightings of from 8 to 15 percent, that is, the weight of febric after treating and drying should be tris much greater than that of the original dry febric. In the imersion mothod the material is soaked in the solution until thorougly saturated (about 15 to $20 \mathrm{~min}$ ). If the wet fabric is wrung out by hand, it will usually weigh aporoximetely 100 percent more than the original dry fabric, and the chomicals left in the raterial after drying will approximate their percentage concentration in the treating solution. However, if $a$ mechanical wringer is used, more of the solution is likely to be extracted and a more concentrated solution mey be necessery to obtein tho desired weighting of salts in the fabric. The concentrations suggested of the watersoluble chemicels (Type. 3) of sec. IV are, in general, suitable for hand wringing, and the quantity of water used should be varied to suit the nethod of aoplication sind type of fabric treated. If the concentration of solution desired exceeds the limit of solubility of the chemical, the. wringer prossure may be reduced so thet a less conoentrated solution will provide the required weighting of salts in the favric. The following table of solubilities of scne of tho most corilonly used salts will indicate the concentrations which can be obtained. 
Table 1. Solubilities of Flameproofing Chemicals Solubilities - - in parts by weight of salt per 100 parts of water Ammonium chloride, $\mathrm{NH}_{4} \mathrm{Cl}$ $29.7 \quad 37.3 \quad 41.6 \quad 59.9 \quad 76.0$ Ammonium sulfate $\left(\mathrm{NH}_{4}\right)_{2} \mathrm{SO}_{4}$ $\begin{array}{lllll}70.7 & 75.7 & 78.1 & 91.7 & 103.3\end{array}$ Diammoniun phosphate $\left(\mathrm{NH}_{4}\right)_{2} \mathrm{HPO}_{4}$ Ammonium carbonate $\left(\mathrm{NH}_{4}\right)_{2} \mathrm{CO}_{3}$ Boric acid, $\mathrm{H}_{3} \mathrm{BO}_{3}$ $43.6 \quad 59.4$ 93.8

Borax, $\mathrm{Na}_{2} \mathrm{~B}_{4} \mathrm{O}_{7} \cdot \mathrm{IOH}_{2} \mathrm{O}$

Sodiur tungstate, $\mathrm{Na}_{2} \mathrm{WO}_{4} \cdot 2 \mathrm{H}_{2} \mathrm{O}$ 55.7

Di-sodium phosphate $\mathrm{Na}_{2} \mathrm{HPO}_{4} \cdot 12 \mathrm{E}_{2} \mathrm{O}$

$\begin{array}{rrrrr}2.6 & 4.9 & 6.6 & 18.5 & 39.4 \\ 2.1 & 4.9 & 7.6 & 35.3 & 75.7 \\ 41.0 & 82.2 & & & 109.5\end{array}$

AIUn, $\mathrm{KAI}\left(\mathrm{SO}_{4}\right)_{2} \cdot 12 \mathrm{H}_{2} \mathrm{O}$

$\begin{array}{llll}5.6 & 10.8 & 15.2 & 65.9\end{array}$

Lead acetate $\mathrm{Pb}\left(\mathrm{C}_{2} \mathrm{H}_{3} \mathrm{O}_{2}\right)_{2} \cdot 3 \mathrm{H}_{2} \mathrm{O}$ $23.0 \quad 51.7 \quad 81.2$ Zinc sulfate, $\mathrm{ZnSO}_{4} \cdot \mathrm{7H}_{2} \mathrm{O}$ $74.6 \quad 96.6 \quad 110.5$

(d) Application in Comercial Launary Equipments

Treatment with flameproofing solutions in commercial laundry operations requires certain precautions if the desired results are to be obtained. The temperature of the solution and operating temperatures of the equipment need, in general, to be lower than for the regular laundry process. Partioular attention must be given to regulation of the extraction procsaure and to the concentration of the flameproofing solution in order to insure the proper final weighting of chemicals in the febric.

The articles to be flemeproofed should first be laundered with the usual number of suds and rinses, end extracted. When highly soluble flemeproofing chenicals are used, the articles may be passed directly from the extractor to the flemeproofing solution, since the solution concentration cen easily be increased to compensate both for the water remaining in the fabric before treatment and for the loss of solution fron the fabric during the subsequent extraction. If less soluble chomicals, such as borax and boric acid, are used, it may be advisable to ary the articles before the flameproofing treatment, as the concentration of these compounds in solution is linited. Increased, solubility of such chemicals may be obtained by heating the solution, but this is limited by the danger of tendering the fabric at high temperatures. Dilution of the 
dry may be minimized by increasing the proportion of solution to goods to be treated.

Treatment may be accomplished by immersion and soaking for 15 minutes in a tank of the flameproofing solution or by agitation for about 5 minutes in a wheel or washer containing the solution. If the articles have been dried before the flameproofing treatrent, the solution should be used in a concentration about twice the desired final weighting of chemicals, to allow for removal of the solution during extraction. A 15 minute extraction in tho usual equipment leaves moisture in the fabric to the extent of about 50 percent of its dry weight; that is, 150 lbs of the damp, extracted materials will weigh approximetely 100 lbs vihen dried. Hence, if a final weighting of 10 percert of ihe flemeproofing chemicals is required in the fabric, the treating solution should be used in a concentration of abuv' 20 percent so that, after extraction, a 10 percont weight ing will. remain. If the naterials are only extractea end not dried before the flameproofing treatment, a somewhat more concentrated solution will be required depending on the amount of treating solution used in relation to the quantity of materials treated and the water remaining in the fabric before treatment. 'The articles may be taken from the flareproofing solution, extracted and finished in the usual manner. The extractor and other equipment in which the flaileproofing solution is used should be equipped to permit recovery of the solut,ion which may be used repeatediy, assuming clean and fast-colored fabrics.

Possible damage to treated materials in the tumbler will depend upon the type of fabric, the troating solution used, and the temperature and time of the tumbier operation. More information on these factors is needed. If the goods can be passed directly from the extractor to the mangle for finishing such possible effects are avoiaed but consideration should be given to proper mangle temperatures.

In treating curtains, volour or volvoteen àreperies and the like, some laundries prefer a procedure which is longer but more suiteble for certain fabrics. The llameproofing solution is used in a concentration about equal to the final weighting of chemicals desired, and cxtrection is reduced to a time that leaves about 100 percent moisture in the fabric. The articles are then hung up to dry. For special work this method may offer definite advantages and avoids possible demage from heating in the tumbler.

IV. FROCESSES AND FORIULAS

The flameproofing proceșes for textiles given below are grouped into three main divisions as outlined in the preceding section. 
No formulas covered by patents or based on patented proprietary compounds are included except that some of the processes coming under the general description of Type 1 may be patented. Formulas are stated in tems of parts by weight and, also, where water is the solvent, in avoirdupois weight of chemicals. and volume of water in U. S. gallons. Smaller or larger volumes can of course be prepared by decreasing or increasing all constituents, including the solvent, in the same proportion.

1. Processes Combining Fireproofing and Weatherproofing, Type 1

No. 1. Finishes meeting requirements of Federal Specification CCC-D-746 and similar specifications.

The essential components of the treating corpounds may be described in general as follows:

(a) An organic binder, such as chlorinated paraffin, chlorinated rubber, or vinyl resins as a film-forming material which acts as a water repellent and also affords some degree of fireproofing. With the addition of proper plasticizers, such as tricresyl phosphate or alkyd resins, this binder counteracts much of the stiffening effect of the inorganic ingredients on the fabric.

(b) Inorganic flaneproofing agents such as oxides, borates and others.

(c) Figments, fillers, stabilizers, and other materials such as mildew-proofing agents which add specific desirable properties. Pigments not only give color, but, being opaque, they also serve to protect the finish from the action of sunlight which apyears to decompose the chlorinated paraffin to a certain extent with the formation of hycrochloric acid. The finish may be Iurther stabilized by the mncusion of basic compounds such as calcium carbonate, meciesium carbonate and aluminum stearete, to absorb and counterart the hydrochloric acid which has a tendering effect on tho fabric. The protection afforded by these materials is importani not only to preserve the finish in its proper condition over a period of use, but also to increase the durability of the treated fabric.

(a) An organic solvent in which the other ingredients are dissolved or suspended during application the solvent must be volatile and evaporate entirely in the dryjng. Water-in-oil emulsions have also been successfully used for impregnation.

The fabric is impregnated most effectively in a processing plant but compounds which will give comparable protection when brushed or sprayed on untreated canvas, or when used to renew the treatment after a period of use and exposure, are available. 
Manufacturers usually advise renewal after one year's exposure and at varying intervals thereafter, depending on conditions of use and exposure. These treatments afford considerable protection to the fabric from the effects of weather, microorganisms, and handing, and may extend materially the useful life of the fabric.

A considerable degree of permanence has been achieved in these finishes, but the weightings necessary for effective protection are high, from 40 to 60 percent of the weight of the cloth. They are not suitable for use on fine fabrics, for so heavy a loading alters the characteristics of the fabric more than is compatible with use for clothing and decorative purposes. The numerous compounds effective in lighter weightings are not suitable for outdoor exposure since they are either water-soluble and removed by leaching, or, when insoluble, sufficiently permanent impregnation to withstand any extended period of outdoor exposure has not yet been achieved. If treatments can be developed that effect a basic and permanent change in the cellulose molecule these limitations may be overcome in whole or part. Attempts have been made to bind on water-soluble flameproofers with an over-coat of resin, but the results have not been promising.

\section{Water-Resistant Finishes, Type 2}

The degree of resistance to water leaching will depend on the details of application and loading as well as the chemicals used. Full resistance in this respect cannot be premised for any of them. Some information on the attainable degree thereof, if known, is given under the respective treatments.

No. 2. Chemical Warfare Service Process (10) Type 2

Antimony oxide, $\mathrm{Sb}_{2} \mathrm{O}_{3} \ldots \ldots \ldots \ldots \ldots \ldots$ parts

Vinylite VYHH (vinyl chloride-acetate copolymer) 60 parts

Methyl ethyl ketone ................420 parts

(This amount of methyl ethyl ketone is suggested for trial, but it should be varied as necessary to produce a 35 percent pickup of the $\mathrm{Sb}_{2} \mathrm{O}_{3}-\mathrm{Vinylite}$ fraction on the cloth.)

Where the white color of antimony oxide is objectionable, part of it may be replaced by suitable coloring pigments matching the color of the untreated fabric. Improvement in glowproofing will be effected if 27 parts of zinc borate are added.

The Vinylite is dissolved in one half the required methyl ethyl ketone and the antimony oxide added with agitation. If equipnent is available, the mix is put through a paint mill to 
produce a more stable dispersion. Before use, sufficient methyl ethyl ketone is added to give a suitable viscosity and pickup.

AlI sizing and soil must be removed from the cloth by thorough washing and rinsing before treatment. The dry cloth is passed through the impregnating $\mathrm{mix}$ and put through squeeze rolls to remove the excess. The setting of the squeeze rolls may be varicd to help adjust the pickup to the desired amount. The cloth is carefully dried, then softened by treating for 30 to 60 minutes on a scouring machine using a. 0.2 percent solution of soap or other suitable detergent at $120^{\circ}$ to $212^{\circ} \mathrm{F}$, depending upon the type of material. It is then rinsed, dried, and may be further softened by treatment on a sanding or sueding machine.

Duck treated by this process has been through 12 commerciel launderings with a loss of treatment of less than 10 percent of an original pickup of 40.4 percent and with no apparent loss in flameproofing. The treated fabric is also unaffected by stoddard or similar dry cleaning solvents, but will not withstand cleaning with chlorinated solvents. This treatment is recommended for cotton, wool and wool-rayon fabrics.

There has been some indication that antimony oxide has a toxic effect upon certain individuals and it is possible that fabrics carrying this treatment and worn next to the skin may be found irritant in some cases.

No. 3. Perkin Process (6) Type 2

Solution A --

Sodium stannate, $\mathrm{Na}_{2} \mathrm{SnO}_{3} \cdot 3_{2} \mathrm{O} \ldots \ldots \ldots .41 .8$ parts 11 Ib 13 oz Water ............................. parts 12 gal Solution B --

Armonium sulfate $\left(\mathrm{NH}_{4}\right)_{2} \mathrm{SO}_{4} \ldots \ldots \ldots \ldots$. 15.0 parts 15 Ib

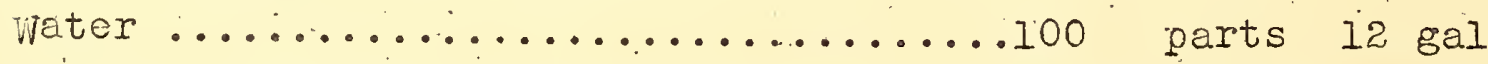

The cloth is thoroughly washed to renove oils, waxes, or other substances which might reduce its absorptive power; it is then acidified with acetic or other weak organic acid, washed, dried, and immersed and agitated in solution $A$, then squeezed ard dried again. It is next run through solution $B$, squeezed, dried, and washed in cold water to remove the sodium sulfate formed by the interaction of the salts in the two 
solutions. If desired by the finisher, the sodium sulfate may be left in the cloth.

The goods must be heevily squeezed after passing through the solutions, since the pressure seems to increase the affinity of the cloth for the stannic oxide formed, with the consequent deposition of more of the latter. The process may have to be repeated or more concentrated solutions used, preferably the fomer, in order to obtain the required loading of tin oxide which should approximate 20 percent.

The process has been used for flannelettes and other Iight cotton goods. Perkin states. that the treatment does not injure delicate colors, and is not harmful to the skin; that the stannic oxide gives tho cloth a softer and fuller feel than that of the original flannelette, and that the material is considerably strengthened by the process.

The treatment, particularly in the lighter loadings, may not prevent propagation of glow. Thile originally indicated as withstending as neny as 20 washings without loss in effectiveness, recent work has shown a large loss with only a few reguler washings in presont-day launary equipment, each involving severel suds anc rinses of relatively long duration.

The difficulty experienced by many investigators in obtaining an effective application of this process may be due in part to the absorption of alkali by the stannic oxide. Leatheman (11) recommends the use of ferric sulfate or chloride instead of ammonium sulfate. as the precipitating agent in order to maintein an acid solution.

3. Water-soluble Treatments, Type 3

No. 1. Kling and Florent in (5) Type 3

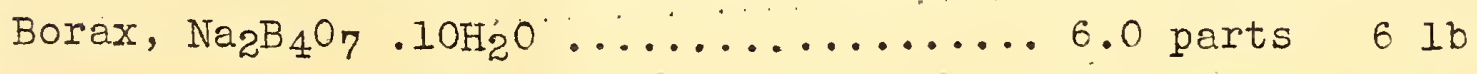

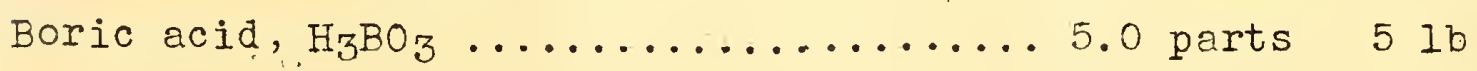

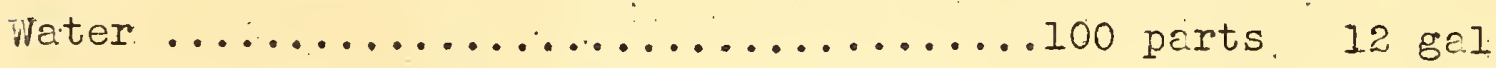

The fabric is steeped in a cool solution until thoroughly impregnated, then dried. Heavy applications by sprey or brush are usually reasonably effective. Such applications may have to be repeated two or three times with drying between applications to get the desired degree of flameproofing. The treatment has been used for many, kinds. of fabrics, including theater scenery. Grove-Palmer (13) recommends it for rayon. As in the case of most of the other formulas listed, care must be taken in ironing to avoid aiscoloration by heat. 
The treatment is effective in weightings of from 8 to 12 percent depending upon the type of fabric. Fand wringing from a solution of the concentration suggested above gives a weighting of 10 to 12 percent after arying.

No. 5. Ramsbottom and Snoad (1) Type 3

Borax, $\mathrm{Na}_{2} \mathrm{~B}_{4} \mathrm{O} 7 \cdot \mathrm{IOH}_{2} \mathrm{O} \ldots \ldots \ldots \ldots \ldots \ldots \ldots \ldots \ldots . \ldots \ldots$ parts 7 Ib

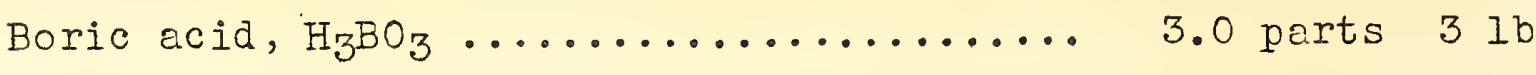

water .................................. parts 12 gal

The amount of water may be varicd, and should depend upon the absorptive capacity of the fabric to be treated. In general, loadings from 8 to 10 percent of the weight of the dry cloth will be found effective. Hand wringing from the above solution will give approxinately these weightings. Fabrics so treated retain their flexibility and softness. Thoy do not becone dusty, feel damp, or lose their strength under ordinary conditions of use. The naterials are non-poisonous and do not promote the growth of destructive microorganisms. It has been found to flameproof airplane cloth as over-coated with acetate (14). Brosnan (15) recomends the solution in 7 percent strength for rayon and sheer fabrics.

No. 6. Army Quartermaster Corps - Type 3

Borax, $\mathrm{Na}_{2} \mathrm{~B}_{4} \mathrm{O} 7 \cdot \mathrm{IOH}_{2} \mathrm{O} \ldots \ldots \ldots \ldots \ldots \ldots \ldots \ldots$ parts 7 Ib

Boric acid, $\mathrm{H}_{3} \mathrm{BO}_{3} \ldots \ldots \ldots \ldots \ldots \ldots \ldots \ldots \ldots \ldots$ parts 3 Ib

Diammonium phosphate $\left(\mathrm{NH}_{4}\right)_{2} \mathrm{HEO}_{4} \ldots \ldots \ldots \ldots$ parts 5 Ib

Water .............................. parts $13-1 / 5$ gal

This formula gives very satisfactory rosults both in flameproofing and glow proofing. It will be found effective in weightings of 7 to 15 percent depending upon the fabric treated. Hand wringing from the above solution gives weightings of about 10 to 12 percent.

No. 7. Matthews (16) Type 3

Ammonium phosphate, dibasic $\left(\mathrm{NH}_{4}\right)_{2} \mathrm{HPO}_{4} \ldots . .7$ parts $7-1 / 21$ b

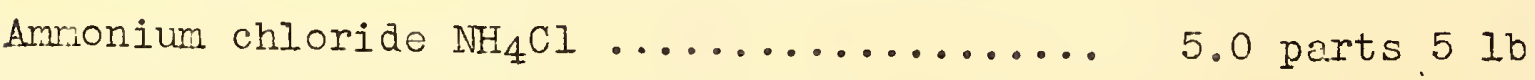
Amronium sulfate $\left(\mathrm{NH}_{4}\right)_{2} \mathrm{SO}_{4} \ldots \ldots \ldots \ldots \ldots$ parts 5 Ib Water ................................... parts 12 gal 
No. 10. National Bureau of Standards - Type 3 Sodium tungstate, $\mathrm{Na}_{2} \mathrm{WO}_{4} \cdot 2 \mathrm{H}_{2} \mathrm{O} \ldots \ldots \ldots 24.0$ parts 24 Ib Ammonium phosphate, dibasic $\left(\mathrm{NH}_{4}\right)_{2} \mathrm{HPO}_{4} \ldots 6_{6} .0$ parts 6 Ib Water .................................. parts 12 gal

Hand wringing from the above concentration produces a loading of about 30 or 31 percent. It is very effective in preventing flaning, but there is some afterglow.

No. 11. Matthews (16) Type 3

Sterch (or flour, sago, dextrin, etc.) .... 22.0 parts 22 lb Sodium tungstate, $\mathrm{Na}_{2} \mathrm{WO}_{4} \cdot 2 \mathrm{H}_{2} \mathrm{O} \ldots \ldots \ldots \ldots . . . .11 .0$ parts $11 \mathrm{lb}$ Borex, $\mathrm{Na}_{2} \mathrm{~B}_{4} \mathrm{O} 7 . \mathrm{IOH}_{2} \mathrm{O} \ldots \ldots \ldots \ldots \ldots \ldots \ldots \ldots$ parts $7 . \ldots \ldots$

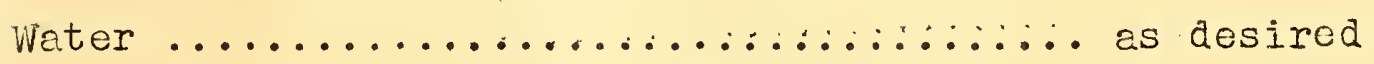

This formula is used for sizing. Although the tungstate and borax afford some fire-retardant effect, their proportion relative to the amount of starch is so low that adequate flane protection is not provided.

V. TESTS AND TESTING NETHODS

Through the years of development of flameproofing treatments, various methods of testing and comparing the effectiveness of such treatments have been devised by different experimenters. In the earlier work on test methods, particular recognition should be accorded the work of Whipple and Fay (4), J. R. Freeman (4), and Remsbotton and Snoad (I) who thoroughly investigated the subject of tests and testing procedure. In 1938 the National Bureau of Standards (18) made a comparative study of a number of testing procedures, including the National Bureau of Standards vertical flame test, the Underwriters' Laboratories flammability test, the Freeman stove pipe test, the Whipple-Fay burning test, the British Standards Institution test, and a fold test. As space does not permit a full. discussion of the verious testing methods developed, descriptions in this circular will be limited to those in present use at the National Bureau of Standards.

\section{Vertical Flame Test}

This test is similar to one devised earlier by Rarsbottom and snoad. It is fairly severe and is the performance test required by Federal Specification CCC-D-746 for Duck, Cotton; Fire, Water and Weather Resistent (12) and is suitable for flameproofed textiles, in general. 
Either the cloth may be impregnated directly with this solution, or the starch sizing may be made up with it. It has been used for curtains; Matthews recommends it for cotton fabrics in general. The ammonium chloride and, to less extent, the ammonium phosphate are hygroscopic and the use of the formula for materials other than those in dry locations may not be advisable. The treatment is effective in weightings of 10 to 18 percent depending upon the type of fabric treated. Hand wringing from a solution of the above concentration gives weighting of about 16 to 18 percent.

No. 8. Martin (16) Type 3

Ammonium sulfate $\left(\mathrm{NH}_{4}\right) \mathrm{2SO}_{4} \ldots \ldots \ldots \ldots .6 .0$ parts $8 \mathrm{Ib}$ Ammonium carbonate $\left(\mathrm{NH}_{4}\right)_{2} \mathrm{CO}_{3} \cdot \mathrm{H}_{2} \mathrm{O} \ldots \ldots .2 .5$ parts $2-1 / 2 \mathrm{Ib}$

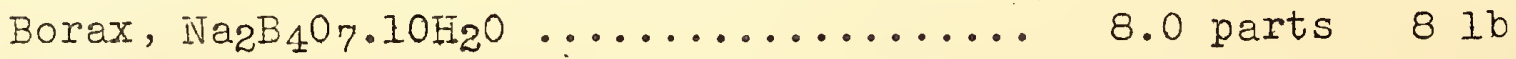

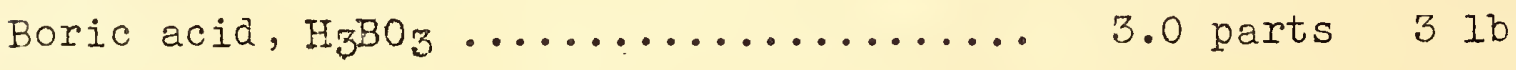

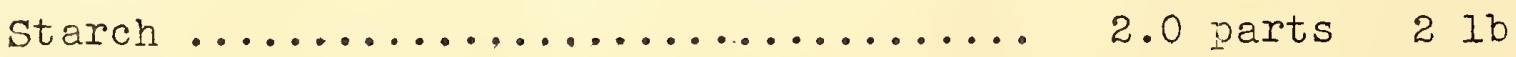
Dextrin 0.4 parts $6-1 / 2$ oz

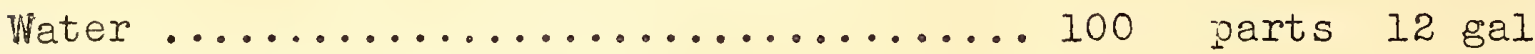

The anount of water may be varied as desirea. The mixture is applied at $86^{\circ}$ to $100^{\circ} \mathrm{F}$. It is useful for many purposes, particularly for laces, curtains, and aprons. It is effective in loadings of 14 to 28 percent depending upon the fabric. Fand wringing from the above concentration deposits a loading of about 28 percent.

No. 9. Chesneau (17) Type 3

Sodium tungstate, $\mathrm{Na}_{2} \mathrm{WO}_{4} \cdot 2 \mathrm{H}_{2} \mathrm{O} \ldots \ldots 20.6$ parts $20 \mathrm{Ib} 9-1 / 2 \mathrm{oz}$ Sodium phosphate, dibasic,

$\mathrm{Na}_{2} \mathrm{HPO}_{4} \cdot 12 \mathrm{H}_{2} \mathrm{O} \ldots \ldots \ldots \ldots \ldots \ldots \ldots . . .60 .6$ parts $9-1 / 2$ oz water............................ 100 parts

Sodium tungstate has been used for flameproofing theater scenery in Paris, Iondon, and elsewhere. The addition of the sodium phosphate is recommended by chesneau to prevent crystallization, resulting from the formation of an acid sodium tungstate. Fiand wringing from the suggested concentration gives a weighting of about 23 percent. The treatment is effective in preventing flaming, but afterglow continues for a considerable time, and may seriously extend the char. 
A specimen 2 in wide by $12-1 / 2$ in long is clamped in a vertical position with the lower end free, and with $1 / 2$ in of the upper end in the clamp, so that a 12 in length is exposed. The lower end of the specimen is $3 / 4$ in above the top of a Bunsen or Tirrill gas burmer which has a tube of $3 / 8$ in inside diameter. A $1-1 / 2$ in luminous flane is used for ignition and is applied to the center of the lower end of the specimen for 12 sec. To protect the sample from drafts, the apparatus is enclosed in a sheet metal shield 14 in wide, 12 in deep, and 30 in high, open at the top, and provided with a door containing a glass inset for observation of the burning specimen. A metal bar, secured to the base of the burner and extending outside the cabinet through a slot in one side, permits nanipulation of the burner without opening the door. In this way the burner is noved under the specinen for the ignition period only, and the flame is left burning continuously throughout a series of tests.

A record is made of the tine the specinen continues flaming after the igniting flame is removed, the time of glow after fleming has ceased, and the char length. The char length is defined as the distance from the end of the specinen which was exposed to the fire to the end of a tear made lengthwise through the center of the cherred area in the following way. A hook is inserted ir the specimen at one side of the charred aree $1 / 4$ in in from the adjacent outside edge. A weight, which with the hook is equal to approximately 10 percent of that reauired to tear the unburned cloth, is attached to the hook, and a tearing force is applied to the soecimen gently by grasping the corner at the other side of the char and raising the specimen and the weight clear of the support.

The following indicates satisfoctory performance of flameproofed meterial:

No specimen shall continue flaming for more than 2 seconds after the igniting fleme is witharawn. The avernge length of char of 10 specimens shall not be more than $3-1 / 2$ in, and the maximum length of cher for any one of the 10 specimens shall not be more than $4-1 / 2$ in. For very thin fabrics, however, these requirements are perhaps somewhat severe. While the flame spread is greatest for the specimen in vertical position as in this test, it is not as severe as a muitiplo vertical strip or fold test but gives a greater difference in results between well-treated and poorly-treated fabrics.

Although fairly consistent results have been obtained with this equipment, the following modifications have been applied recently to enable closer control of test conditions:

Making the specimen wider and securing the vertical edges in a light sheet metal clamp to give an exposed width of 2 in centered over the flame; 
Connecting the gas supply line for the burner to a gas chamber to reduce fluctuations in the flame; and

For the same purpose, applying top closure to the shield or box around the burner with a baffled vent placed therein above the burner location.

\section{Clamp Field Test}

This test (19) was designed for field use and gives results comparable to those of the vertical laboratory flame test described above. It may be applied to any horizontal edge or slit in the fabric (or any edge which can be placed in a horizontal position for testing). Without the necessity of cutting out samples or, in general, of removing the material from its position.

The clarp is made of duplicate rectengular pieces of sheet metal about $1 / 16$ in thick, with an area 2 in wide by 5 in deep cut out from the center of one end, leaving U-shaped plates. The two plates are clamped together by spring type paper clips, $1-1 / 4$ in wide, at the ends of the $U$ prongs. The clamp is used with the $U$ in en inverted position, the cioth being slippea between the plates until the horizontal edge of the cloth is even with the ends of the U prongs. Thus, an area of cloth, 2 in by 5 in is exposed, held in a vertical position and firmly clarped in a metal shield which prevents flane from spreading beyond the exposed area. A paraffin candie of $3 / 4$ in diameter is used as the source of ignition and is cerried in a holder hinged to one side of the clamp in such manner that it may be swung away from the fabric for adjustment. When used for ignition, the candie holder swings ageinst a stop when the center of the candle is directly under the 2 in wide exposed lower edge of the specimen. Before use, the tapered portion of the cande is allowed to burn away until a nomel constant flame is obteined. It is then adjusted in the holder so that the top of the wick will be $1 / 10$ in below the edge of the fabric when in position. For ignition, the flame is applied to the edge of the fabric: for 12 seconds.

A satisfactorily flameproofed fabric will meet the following requirements. It will not continue flaming more than 2 seconds after the igniting fleme is removed. The average length of cher in three tests will not be nore than $2-1 / 2$ in. By length of char is meant the distance from the edge of the fabric to the end of a tear through the charred area, made by hand with enough force.to tear through the charred or scorched portion but not sufficient to break undamaged threads.

Vertical flame tests, such as those described above, are too severe for satisfactory application to fabrics which have not been flameproofed, since nearly all untreated fabrics burn 
so rapidly that little differentiation is possible. For the comparison of rates-of-burning of such untreated fabrics, the National Bureau of standards has developed the following horizontal test.

\section{Horizontal Rate-of-Burning Test}

A specimen $4-1 / 2$ in wide and $12-1 / 2$ in $10 n g$ is cut from the cloth and slipped into a steel frame which clamps each long edge of the specimen, leaving a center strip 2 in wide and 12-1/2 in long taut and exposed. Marking wires attached to tho frame but clear of the specimen cross it at $1-1 / 2$ in from the end which is to be ignited and 1 in from the other end, which leaves a specimen length of 10 in between wires (fig. 1). The frame is supported horizontally in a metal cabinet, 8 in wide, 15 in long, and 14 in high inside, to protect the burning sample from drafts. Ten $3 / 4$ in holes near the sides in the raised bottom and a I/2-in free space all around under the cover provide ventilation. The front and spaces in the top are glazed to enable observation of the sample.

The sample frame is inserted through a slot in one end of the cabinet and slides on a track until it strikes a stop, when the midale of the end of the specimen will be $3 / 4$ in above the top of a bunsen or Tirrill $3 / 8$ in gas burner tube. A 1-1/2 in Iong luminous flame, obtained by shutting of $f$ the air inlets to the burner, is used for ignition and may be left burning continuously throughout a series of tests. The time required for the flame front to travel the 10 in between the marking wires (a $1-1 / 2$ in length burns before the timing is started) is measured with a stop watch, from which the rate of burning is calculated.

The dimensions of the eabinet and method of inserting and igniting the specimen can be varied somewhat from the above without appreciably changing the results. If matches or candies are used for ignition, the end to be ignited is left protruding until ignition is accomplished, when it is pushed inside. There should be sufficient ventilation for free combustion without direct drafts on the burning sample. A 1-1/2-in length thereof should hurn before the significant length is reached over which the burning rate is deternined, to obtain a uniform and easily observable start for the flame at the border. of this portion of the sample.

The samples should be conditioned at $140^{\circ} \mathrm{F}$ for about one hour before testing. Unless tested immediately they should be stored under conditions that will prevent undue humidification from atmospheric moisture. Any nap or pile on a fabric should be raised and fluffed before test. The rate of burning is to he given as the average from not less than five tests except that in case there is a spread of more than 40 percent of the 
average between individual results, ten tests are to be made and the average rate of burning based on the five highest rates from the individual tests.

Most fabrics when subjected to this test burn at a rate well under 15 in per minute. Some fine-napped materials have shown a flash rate (flame flashing through the nap) of 400 in per minute. Light netting and thin coated fabrics give intermediate results.

\section{Conditioning of Test Samples}

A procedure for conditioning samples before testing, regardless of the test employed, has not been satisfactorily standardized, although it is generally agreed that conditioning is an important factor in performance. For most tests of textiles -- strength, weight, etc. -- the samples are regular$1 y$ conditioned for at least 24 hours at $70^{\circ} \mathrm{F}$ and 65 percent relative humidity prior to testing. It is questionable whether as high relative humidity as 65 percent is representative for fire hazard tests since room humiditics, particularly during the heating season, are generelly much lower. It has been the practice at the riational Bureau of Standards to dry the samples in a large ventilated oven at temperatures of 100 to $120^{\circ} \mathrm{F}$ until equilibrium is reached, after which they are kept in a container conditioned with chemicals to have relative humidity of about 20 percent. The preliminary drying, particularly of samples that have been subjected to accelerated weathering, is important since the humidity jar cannot be depended on to abstract very much moisture from the samples.

VI. REFERETCES

1. Ramsbottom, J. 巴., and Snoad, A. W., Fireproofing of fabrics. Fabrics Co-ord. Research Comm., Dept. Sci. and Ind. Research (Gt. Brit.). First Report, 52 (1925). Second Report, Appendix I (1930).

2. Gay-Lussac, J. I., Note on the property of salts for making fabrics incombustibie. (In French) Ann. Chim. Phys. (2) Vol. 18, 211 (1821).

3. Versmann, F., and Oppenheim, A., On the comparative value of certain salts for rendering fibrous substences non-inflammable. Brit. Assn. Adv. Sci. Rep. 1859, Trans. Sect. Meetings, 86; J. prakt. Chem. Vol. 80, 433 ; J. Franklin Inst. Vol. 39, 354 (1860).

4. Freeman, J. R., On the safeguarding of life in theatres. Trans. Am. Soc. Wiech. Ing. VoI. 27, 71 (1906). 


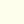


5. Kling, A., and Florentin, D., Protection against fire by fireproofing textiles and wood. (In French) Genie Civil Vol. 80, 180 (1922); (In English) Quart. Nat. Fire Prot. Assn. Vol. 16, 134 (1922).

6. Perkin, W. H., The permanent fireproofing of cotton goods. Proc. Eighth Int. Cong. Applied Chem. Vol. 28, 119 (1912); 2uárt. Nat. Fire Prot. Assn. Vol. 6, 179 (1912); Nat. Fire Prot. Assn. Educ. BuI. D37 (Boston, 1912).

7. Cupery, 阮. E., Sulfamic acid, a new industrial chemical. Ind. Eng. Chem. Vol. 30, 627-31 (1938).

8. Gordon, W. E., Fire retardant treatments for textiles. Am. Dyestuff Reptr. Vol. 30, 305-8 (1941). Flemeproofing textile merchandise, Rayon Text. Month. Vol. 22, 98-9 $(1941)$.

9. Deutsch, N. L., New development in flame-proofing of fabrics. Rayon Text. Iionth. Vol. 17, 689 (1936).

10. Van Tuyle, R., Fireproofing cotton and woolon fabrics. Am. Dyestuff Reptr. Vo1. 32, No. 14, 297 (July 5, 1943).

11. Leatherman, I., U.S. patents No. I,961,108, May 29, 1934; 1,990,292, Feb. 5, 1935; 2,012,686, Aug. 27, 1935; $2,017,805$, oct. 15, 1935; 2,167,278, July 25, 1939; $2,286,744$, June 16,1942 .

12. Fed. Spec. CCC-D-746 for duck, cotton; fire, water, and weather resistant (1939). Obtainable at five cents per copy from Superintendent of Documents, Washington 25, D.C.

13. Grove-Palmer, F., Fire-resisting rayon goods. Am. Dyestuff Reptr. Vol. 19, $715(1930)$.

14. KIine, G. M., Fire-resistant doped fabric for aircraft. J. Research N $\mathrm{NS}$ Vol. 14, 575 (1935); RP788.

15. Brosnan, W. F., Fireproofed textiles. Textile World Vol. 84,2399 (1934). J. Textile Inst. Vo1. 26, A 203 $(1935)$.

16. Matthews, J. Mi., Textile fibers. (John Wiley \& Sons, New York 1924). See pp. 568-577.

17. Chesneau, R., The flameproofing of textiles. (In French) Bul. Soc. ind. Rouen Vol. 60, 265 (1932); (In English) Dyer Vol. $69,357,393$ (19)33); Text. Colorist Vol. 55, 375,420 (1933). 
18. Tests of flameproofed textiles by several methods. Quart. Nat. Fire Prot. Assoc. Vol. 32, 95 (1938).

19. Field test for flameproofed textiles. Quart. Nat. Fire Prot. AssOC. VoI. 33, 351 (1939).

20. Travis, I. S., et al., The impact of wartime requirements on post-war finishing. Am. Dyestuff Reptr. Vol. 31 No. 25,634 (1942).

21. Redmond, J.R., Fire resistant duck. Am. Dyestuff Reptr. Vol. $32,375-8(1943)$.

22. Akin, E. W., Spencer, I. F., and Macormac, A. R., Bibliography on flameproofing of textiles. Am. Dyestuff Reptr. Vol. 29, Nos. 17 and 18, 418-20 Aug. 19, and 445-52 Sept. 2 (1940).

23. The fireproofing of textiles. Contains bibliography of patents and literature references. Textile Research Institute, Inc., N. Y. (1943). 15 pages, mimeographed, $\$ 1.00$ per copy. 